\title{
22. EOCENE BASALTIC PYROCLASTICS AT SITE 253, NINETYEAST RIDGE
}

\author{
B. C. McKelvey, Department of Geology, University of New England, Armidale, New South Wales, Australia \\ and \\ A. J. Fleet, Department of Mineralogy, British Museum (Natural History), London, and \\ Department of Geology, Chelsea College, University of London, England
}

\begin{abstract}
A marine sequence of basaltic pyroclastics totals at least 388 meters at Site 253. Many of the pyroclastics are of a subaqueous origin, produced by the fragmentation of basaltic lavas quenched by seawater. The originally holohyaline tuffs are largely replaced by smectites and some contain abundant analcime and calcite cements.

While the geochemistry of the sequence underlines its altered nature, the higher magnesium contents of samples from the lower part, together with other evidence, suggest a change in the chemistry of the parent magmas from which the upper and lower parts were derived. The rare-earth-element data, discussed elsewhere, are consistent with the suggestion that the Ninetyeast Ridge may be the surface expression of a former mantle plume.
\end{abstract}

\section{INTRODUCTION}

This study of the Eocene basaltic pyroclastics found at DSDP Site 253 on the Ninetyeast Ridge was conducted in two parts. B. C. McKelvey concentrated on the petrographic aspects of the rocks while A. J. Fleet studied their geochemistry. The subsequent arrangement of this contribution into a two-part paper reflects this division. Unfortunately, shortage of time resulting from a strict publication schedule precluded our combining the results of these studies into a general closing discussion.

\section{PETROGRAPHY}

\section{General}

At Site 253 on the Ninetyeast Ridge at least 388 meters of middle Eocene basaltic pyroclastics and basalt-derived sediments underlie 153 meters of upper Eocene to Quaternary nannoplankton oozes and chalks. The water depth at Site 253 is 1962 meters.

The considerable lithological variation shown by the volcanogenic strata allows the 388-meter sequence to be arbitrarily divided into six units. Units II, IV, V, and Vi are composed predominantly of pyroclastic deposits. The sediments of Units I and III, although of similar volcanic provenance, retain few specifically pyroclastic textures and are here treated as epiclastic rather than pyroclastic strata. It is often not possible to determine whether these sediments are reworked tuffs or whether they represent detritus eroded from a volcanic terrain. In many specimens contributions of both origins appear to be present. Such reworking may be due to benthic organisms or current action.

The following nomenclature has been adopted. Those rocks that are essentially juvenile pyroclastics, insofar as they consist of detritus fragmented in an explosive vol- canic episode, are termed vitric lapilli tuffs and vitric ashes according to whether their average grain size is greater or less than $4 \mathrm{~mm}$. The term reticulite is used to refer to the highly variable scoriaceous, pumiceous, and sometimes even foam-like vesiculated fragments of former basaltic glass.

Where specimens show no overall pyroclastic texture in thin section, they are regarded as sandstones, siltstones, etc., of basaltic derivation. Those epiclastic sediments composed of an abundant matrix and containing a dispersed framework are termed diamictites (Flint et al., 1960).

Very often discrimination between pyroclastic and epiclastic sediments has to be based upon thin-section examination, for in hand specimens original vitroclastic textures can be much modified and even obliterated by diagenesis.

Core recovery from the 388-meter sequence totaled approximately 144 meters. This petrographic discussion is based largely upon the examination of 23 thin sections of selected rock types, augmented by data from another 45 smear slides. Six X-ray identifications of clay minerals and zeolites have been kindly supplied by Miss Eva Fejer of the Department of Mineralogy, British Museum (Natural History). Considerable use has also been made of semiquantitative X-ray-mineralogy data of bulk samples (Cook, Zemmels, and Matti, this volume).

\section{Stratigraphy}

Subdivision of the sequence into six units is done to contrast the pyroclastics with the more essentially epiclastic sediments. No formal stratigraphic status is intended for the units. From a lithostratigraphic point of view it would seem better to group Units I and III together as a single formation with Unit II as a member within that formation. Similarly, Units IV and VI could 
be regarded as one formation containing a single contrasting member composed of Unit V.

Accurate positioning of unit boundaries is difficult because of the incomplete core recovery. Only the boundaries between Units I and II at 192.3 meters and the boundaries between Units IV, V, and VI at 483 and 509.5 meters have been observed. The boundary between Units II and III has been arbitrarily placed within Core 29 at about 262.6 meters. However, there is negligible recovery throughout the remainder of this core and of the underlying Core 30 . More complete recovery may have warranted placing the boundary somewhat lower. The boundary between Units III and IV is apparently gradational. This fact, coupled with particularly limited core recovery, makes precise positioning impossible. It has here been placed at 318 meters but it could be as low as 365 meters.

It is very possible that the above positioning of the boundaries is an oversimplification. More complete core recovery may have shown some boundaries to be transitional, composed of interdigitating passage-bed sequences.

\section{Unit I (153.3-192.3 m)}

The sediments consist predominantly of brown, green, and gray medium to coarse sand. Smear slides indicate some very fine-grained vitric ash is present (e.g., at 164.7, 172, and $191.5 \mathrm{~m}$ ). This appears to be of similar composition to the vitric ash of Unit II. In general, recognition of individual beds is difficult as most contacts are gradational. Some beds are at least 1 meter thick, whereas others individually span only 5 to 8 $\mathrm{cm}$. Apart from a coarse lamination, depositional structures are not apparent. Particularly toward the top of this unit the coarsest sediments contain scattered angular fragments, up to $5 \mathrm{~mm}$ in diameter, of originally glassy basaltic material. At the top are $12 \mathrm{~cm}$ of coarse breccia, composed of angular clasts of originally glassy basalt (up to $4.5 \mathrm{~cm}$ ), cemented by abundant calcite.

Fine-grained sediments are rare. At 173 meters a bed of coccolith radiolarian diatomite at least $4 \mathrm{~cm}$ thick was observed, and in the vicinity of 185 meters, several layers of recrystallized coccolith (micarb) chalk, each up to at least $5 \mathrm{~cm}$ thick, occur. No macrofossils have been observed; the only organic remains visible in hand specimen were occasional burrows.

No thin sections were prepared from Unit I, the sediment being either too fragmented by drilling or not consolidated enough.

\section{Unit II (192.3-262.6 m)}

This unit consists largely of dark vitric ash and vitric lapilli tuff. In hand specimen the vitric ash may show no apparent vitroclastic texture and a subconchoidal fracture is not uncommon. Epiclastic lithologies present range from medium to coarse sand and diamictite containing dispersed basalt fragments, down to laminated silt and mud. Lithologic variation is considerable throughout the unit although overall the unit becomes finer grained towards the base where laminated siltgrade sediment predominates. Bedding is more easily recognizable than in Unit I although many boundaries are gently gradational. In general, beds of the finergrained lithologies range up to $20-30 \mathrm{~cm}$ in thickness, while some of the coarsest beds exceed 1.5 meters. Two points of contrast with Unit I are the widespread presence of macrofossil debris and, particularly in the finer-grained lithologies, the presence of scour marks and load casts at bedding contacts. The occurrence of soft-sediment deformation features such as intraformational folding or slumping is frequent. The contact relationships between the sediments and the two thin basalts at 219 and 228 meters have not been observed and it is not known whether these are flows or sills.

Petrography: In hand specimen the vitroclastic nature of the vitric ash has been largely or completely obliterated by the widespread development of a cryptocrystalline smectite of the montmorillonite type (X-ray identification by E. Fejer, Oct. 1973). In thin section this mineral is very reminiscent of palagonite, being deep brown and apparently isotropic.

Sample 253-22-1, 101-103 cm is typical (Figure 1). In thin section delicate reticulite fragments of vesicular and scoriaceous former basaltic glass comprise over $98 \%$ of the detrital component of the rock. These fragments average between 1 and $2 \mathrm{~mm}$ in diameter and are moderately well sorted. Some are turbid or semi-opaque but most are clear. Finer-grained detritus interstitial to this framework is absent. The formerly vitric fragments are replaced by the brown cryptocrystalline montmorillonite and all interstices are filled by the same material. Some of the reticulite fragments contain small laths $(0.2$ $\mathrm{mm}$ ) of calcic plagioclase.

Very minor accessories include occasional small grains $(0.3 \mathrm{~mm})$ of fresh clinopyroxene and fresh calcic

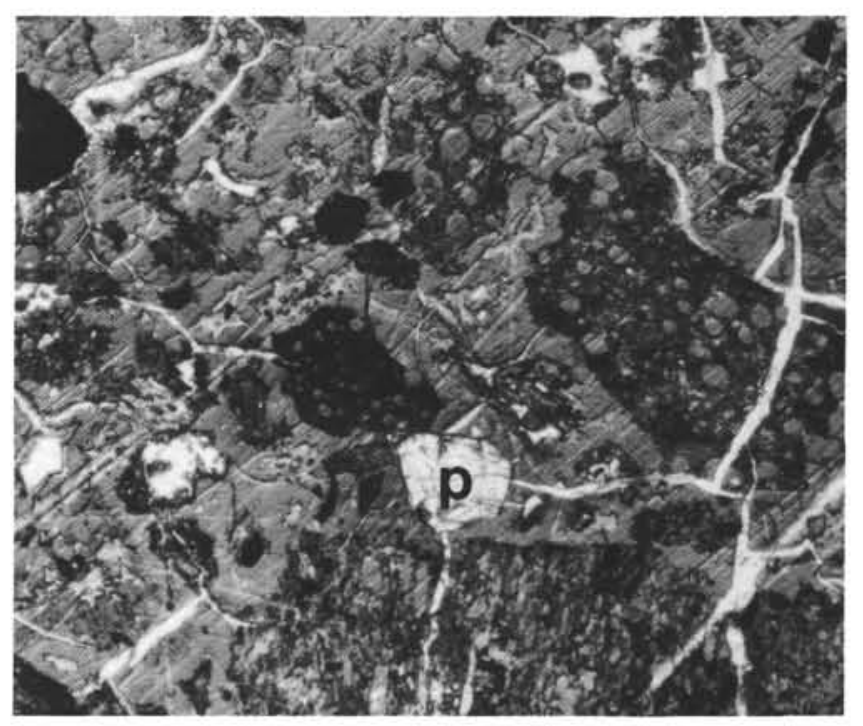

Figure 1. Unit II vitric ash (Sample 253-22-1, 101-103 cm). Vesicular reticulite set in a brown cryptocrystalline smectite cement of the montmorillonite variety. The reticulite varies from barely discernible, highly transparent varieties to turbid and even opaque fragments. Feldspar microlites are absent. A small crystal of fresh clinopyroxene ( $p$ ) is present (lower center). The soft smectite cement is heavily scratched by grinding powder. Plane light; field width $3.4 \mathrm{~mm}$. 
plagioclase (Anss). Also present are occasional fragments $(0.2 \mathrm{~mm})$ of holocrystalline very-fine-grained basalt. Scattered through the slide are a few fragments of partially recrystallized calcareous microfossils.

Sample $253-29-2,95 \mathrm{~cm}$ is very similar but shows less textural variation within the reticulite and more abundant (3\%) calcareous microfossil debris.

In thin section the lapilli tuff contrasts markedly with the vitric ash. Sample 253-24-1, $148 \mathrm{~cm}$ is considered typical (Figure 2). Although the reticulite fragments are replaced by the brown cryptocrystalline montmorillonite identical to that within the vitric ash, the lapilli tuff contains a plentiful coarse $(0.2 \mathrm{~mm})$ calcite cement. The reticulite fragments (up to $4 \mathrm{~mm}$ ) are of extremely irregular and delicate shapes and are all texturally similar internally. Some contain laths of zoned calcic plagioclase. Fine detrital grains interstitial to the reticulite framework are absent. Calcite only rarely occurs in vesicles within the reticulite, most of these being filled by the brown cryptocrystalline montmorillonite. A very few reticulite fragments are replaced by ?clinoptilolite showing very low birefringence. However, the vesicles of these fragments contain only the cryptocrystalline montmorillonite. Rarely, fragments $(1.5 \mathrm{~mm})$ of holocrystalline finegrained basalt containing fresh clinopyroxene and plagioclase are present. No microfossil debris is present.

\section{Unit III (262.6-318 m)}

The sediments comprising this unit are poorly known because of low core recovery, but generally they appear to be similar to those of Unit I. They are mainly medium to coarse green and gray sand devoid of sedimentary structures apart from a coarse lamination. Sorting is

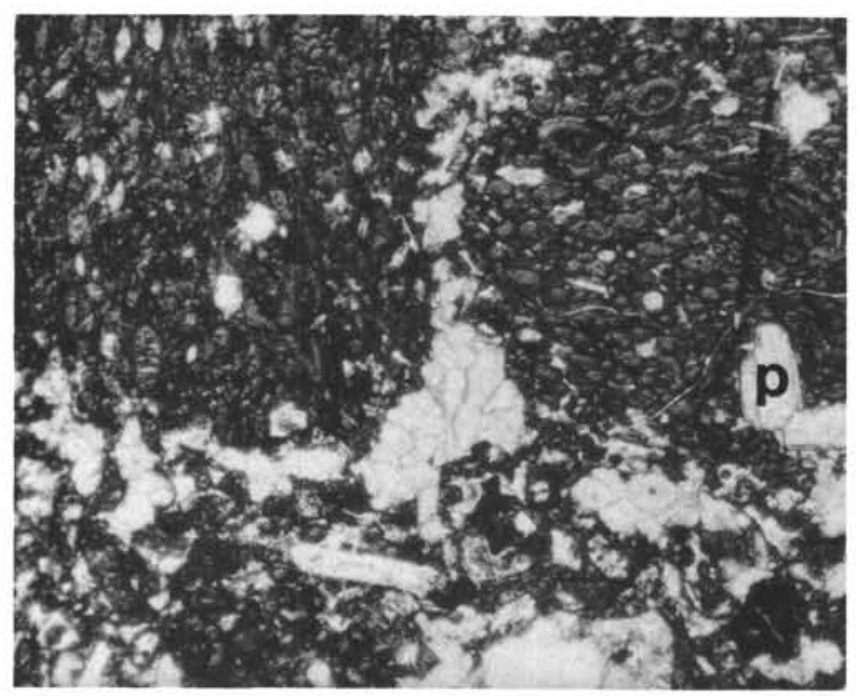

Figure 2. Unit II vitric lapilli tuff (Sample 253-24-1, 148 $\mathrm{cm}$ ). Pieces of originally vesicular reticulite cemented by relatively coarse clear calcite. The reticulite is replaced by a brown cryptocrystalline montmorillonite which also fills most vesicles. A very few small plagioclase crystals (p) and microlites are present. Plane light; field width $3.4 \mathrm{~mm}$. highly variable. In contrast to Unit I, macrofossil debris is abundant, often concentrated in bands parallel to the bedding. Burrows are also common. Discernible bedding boundaries are rare except among the few fine sand and silt lithologies which occur in beds up to $15 \mathrm{~cm}$ thick. The scattered dark fragments of basaltic material, so common towards the top of Unit I, are rare in Unit III. The uppermost horizons of Unit III appear to be weathered immediately beneath their sharp contact with Unit II at 262.6 meters.

Petrography: In thin section these sediments display a highly varied petrography. Although reworked by benthonic organisms or currents, the sediments appear to contain both a contemporaneous pyroclastic contribution of shards or pumice and an epiclastic component of hemicrystalline and holocrystalline lithic fragments.

Sample 253-31-1, 19-23 cm (Figure 3) consists largely of somewhat turbid fine-textured pumice fragments $(0.6$ $\mathrm{mm}$ ) with ragged ends and devoid of feldspar microlites, and a subordinate component of very-fine-grained subrounded, intersertal and pilotaxitic basaltic fragments. The grain size within the latter rarely exceeds 0.2 $\mathrm{mm}$. Angular broken fragments of fresh calcic plagioclase and occasional quartz grains make up about $3 \%$ of the rock. The turbid pumice fragments have devitrified to microcrystalline clay of low birefringence, and, less commonly, to a near-isotropic zeolite. Occasionally, pumice is replaced by calcite. A dark-brown turbid clay matrix binds the framework. Broken calcitic fossil debris is common.

Sample $253-31-3,140-143 \mathrm{~cm}$ is similar but contains much less of the shard and pumice debris indicative of contemporaneous volcanism. Subrounded to subangular basaltic fragments of many textural types abound. Some contain diabasic clinopyroxeneplagioclase xenoliths. The shape of the pumice fragments in these two slides is texturally in marked contrast to the reticulite and similar vitric debris present in the other units.

\section{Unit IV (318-483 m)}

The sediments of Unit IV consist largely of interbedded medium- and fine-grained vitric ash. The medium ash contains both secondary clay-mineral matrices and a zeolite cement. Sorting is markedly better than in Unit III. Scattered macrofossil debris is common but not abundant except in the finest lithologies. Descending in the unit the average grain size coarsens irregularly towards a maximum at a depth of about 440 meters where individual beds appear to be at least 2.5 meters thick. Beneath this horizon the sediments are finely laminated $(1-10 \mathrm{~cm})$ ash overlying a coarse, $40-\mathrm{cm}$ thick diamictite at the base at 482 met.

Petrography: All the ash is very similar and Sample 253-40-3, 101-107 $\mathrm{cm}$ is representative (Figures 4 and 4a). Thin-section examination reveals angular fragments of reticulite and shards, now replaced by a fibrous green or brown smectite identical to the saponite identified in Unit V Sample 253-52-4, 5-16 cm (X-ray identification by E. Fejer, Sept. 1973). An abundant secondary smectite matrix associated with fibrous analcime (X-ray identification by E. Fejer, Sept. 1973) occurs interstitial 


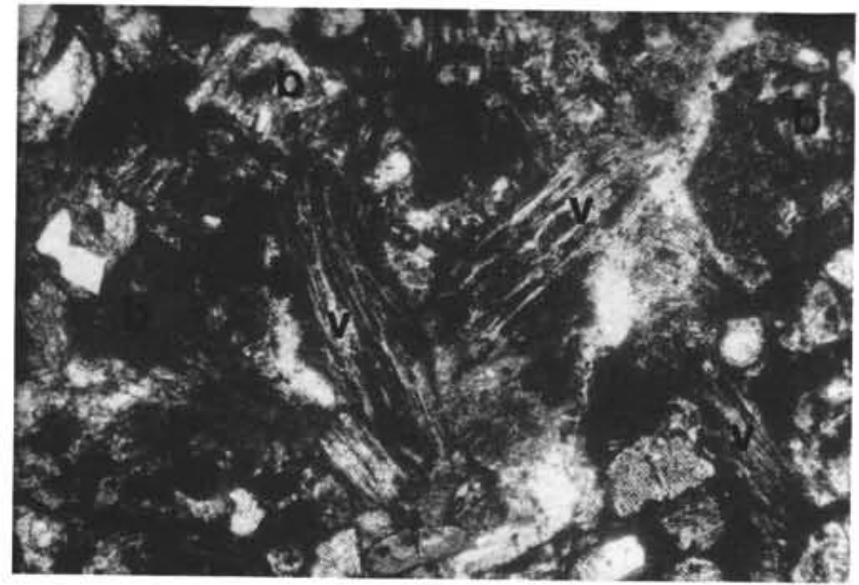

a

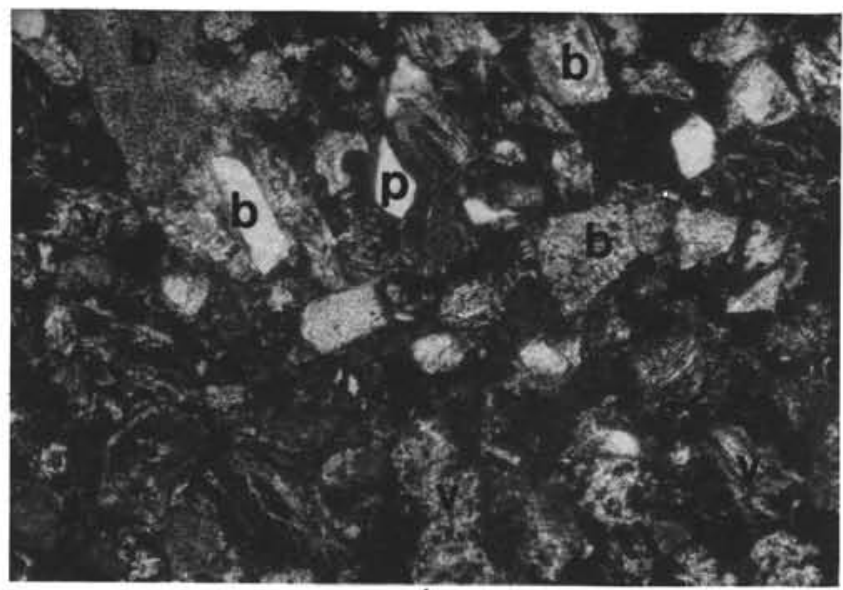

b

Figure 3. (a) Unit III volcanogenic sand (Sample 253-31-1, $19-23 \mathrm{~cm})$. Pumice fragments $(v)$ with ragged ends and turbid fine-grained basaltic rock fragments (b). A dark clay mineral matrix is present. Plane light; field width $2.2 \mathrm{~mm}$. (b) Unit III volcanogenic sand (Sample 253-31-3, $19-23 \mathrm{~cm})$. Irregular fragments of pumice $(v)$ and finegrained basaltic rock fragments (b) set in a dark clay mineral matrix. One basalt fragment is porphyritic and contains a plagioclase phenocryst. A few detrital plagioclase grains $(p)$ are also present. Plane light; field width $3.4 \mathrm{~mm}$.

to the sediment framework (Figure 5). All vesicles in the reticulite are also filled with the smectite. Plagioclase microlites are absent from the reticulite. A coarse framework component much subordinate to the abovedescribed reticulite, consists of turbid,yellowish-brown, originally holohyaline, fragments that show all gradations to completely opaque lithologies. These are much less vesicular than the reticulite. A few (3\%) holocrystalline but very fine-grained pilotaxitic and intersertal basaltic fragments are also present.

Detrital plagioclase $(0.3 \mathrm{~mm})$ varies in amount but is always less than $3 \%$. It appears on morphological evidence to be derived from the turbid, yellowishbrown, originally hyaline, fragments described above.

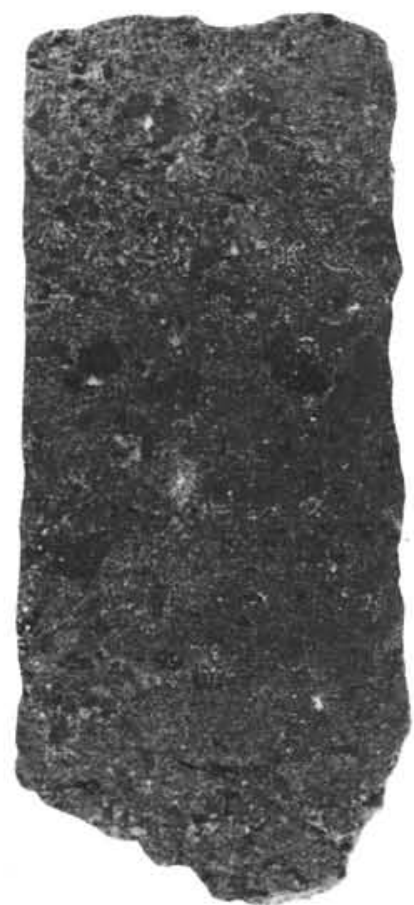

Figure 4. Unit IV vitric ash (Sample 253-40-3, 101-107 cm). A poorly sorted framework or reticulite fragments and finer grained shards replaced by a smectite. Analcime cement (white) is more abundant towards the top of the specimen. Elsewhere interstitial to the framework a smectite matrix predominates. Length of specimen is $6.8 \mathrm{~cm}$.

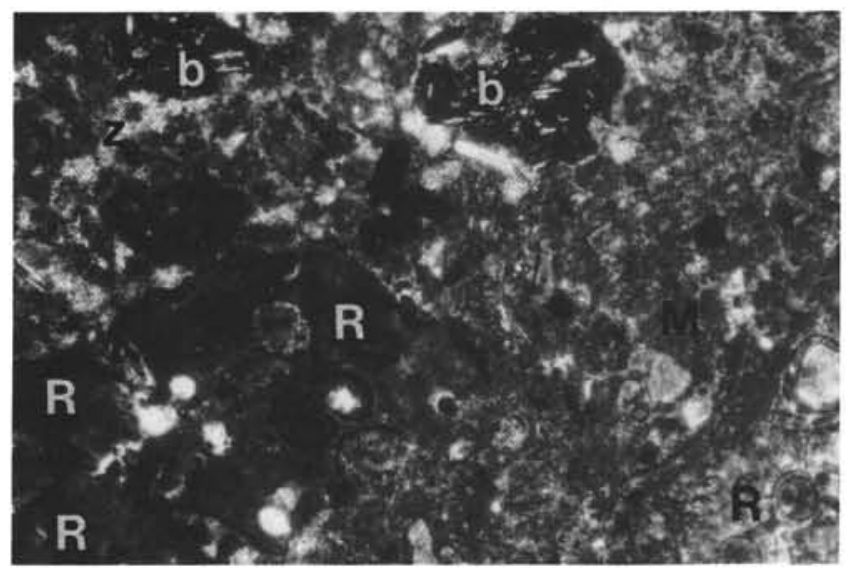

Figure 4a.Unit IV vitric ash (Sample 253-40-3, 101-107 cm). Angular pieces dark green-brown reticulite $(R)$ set in an irregularly distributed secondary smectite matrix $(M)$. Two highly ferruginous basalt fragments containing plagioclase microlites are also present $(b)$. The lighter colored patches within the matrix are of microcrystalline fibrous analcime (z). Plane light; field width $2.2 \mathrm{~mm}$.

The finer-grained ashes (e.g., Sample 253-40-2, 71-78 $\mathrm{cm}$ ) are similar, but differ in that the framework consists only of shards, there being no reticulite fragments (Figure 6). Interstitial to the shards is the secondary smectite matrix and both fibrous and structureless 


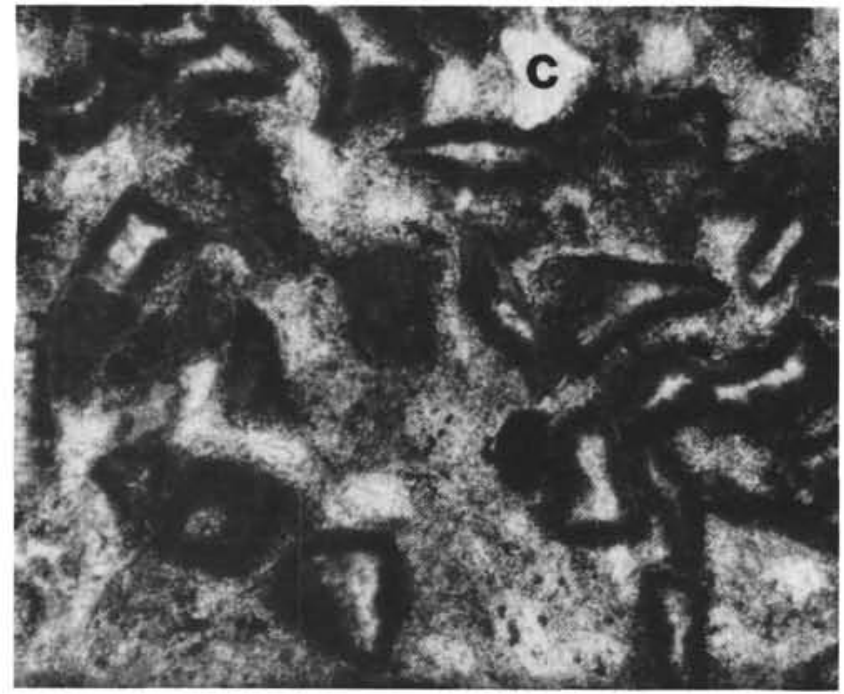

Figure 5. Unit IV vitric ash (Sample 253-40-2, 71-78 cm). The shards show peripheral replacement to a fibrous smectite (saponite). Interstitial to the shards is a secondary saponite matrix (dark) containing lighter colored patches of analcime. Also present is a fragment of organic calcite (c). Plane light; field width $2.2 \mathrm{~mm}$.

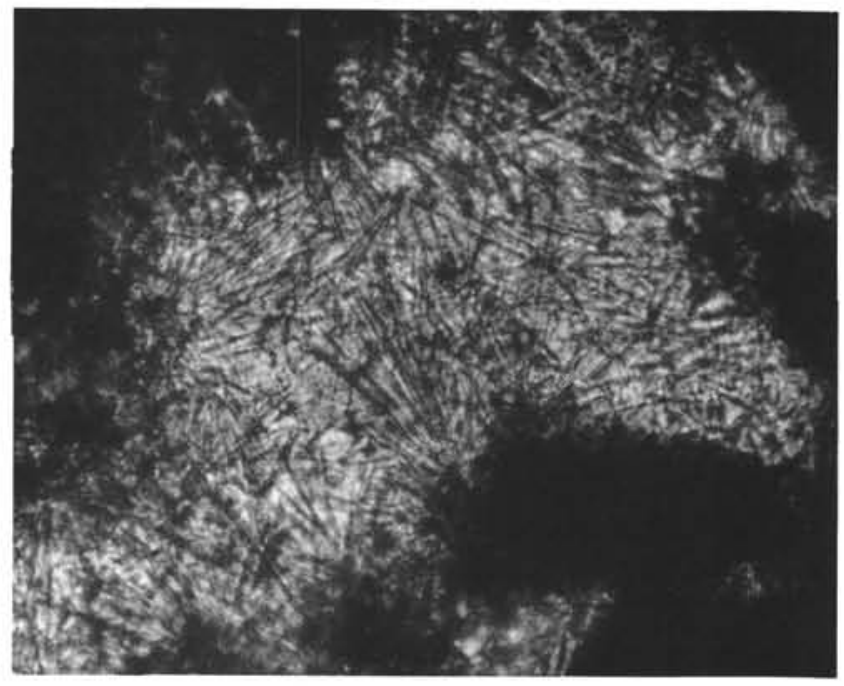

Figure 6. Unit IV vitric ash (Sample 253-40-2, 125-131 cm). Dark-brown angular interstitial-to-dark formerly vitric fragments replaced by a smectite. Plane light; field width $0.35 \mathrm{~mm}$.

analcime. Calcareous microfossil debris is particularly abundant. As previously noted, the contact between Units III and IV is presumably gradational, and all varieties of transitional rock types are to be expected. Sample 253-40-2, $125-131 \mathrm{~cm}$, is an example, being essentially a type-IV vitric ash but containing a considerable heterogeneous epiclastic component derived from a basaltic source (Figure 7).

The morphology of the analcime in these tuffs merits comment. In the youngest horizons (i.e., Sample 253-40$3,101-107 \mathrm{~cm}$ ) it consists only of delicate radiating fibers within interstices (Figure 5). Descending the sequence

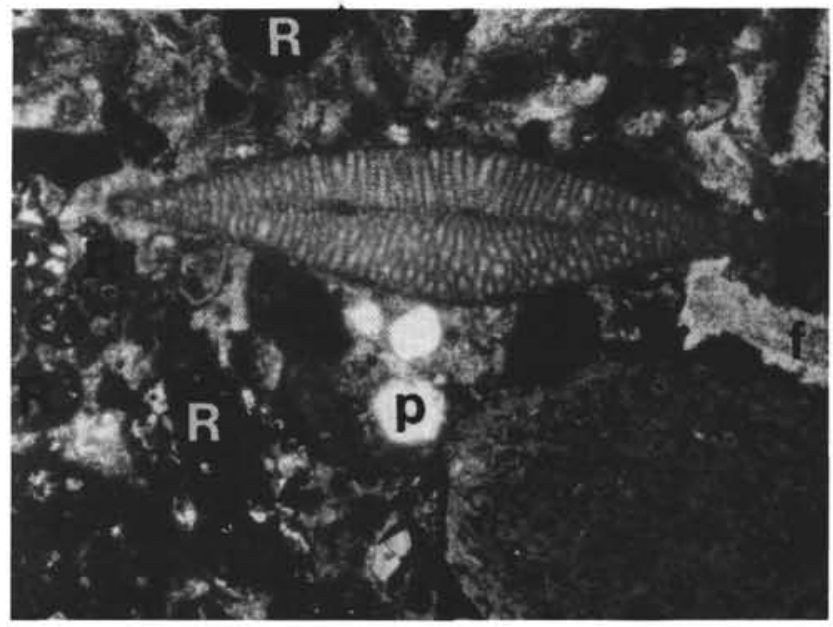

Figure 7. Unit IV vitric ash (Sample 253-40-2, 125-131 cm). Dark-brown angular reticulite fragments replaced by $a$ smectite ( $R$ ), a microfossil, and a large rounded green reticulite fragment (bottom right) set in a fibrous analcime cement. Three plagioclase grains $(p)$ and a macrofossil fragment with calcite overgrowths $(f)$ are also present. Plane light; field width $3.4 \mathrm{~mm}$.

the fibers become less obvious until in Sample 253-47-2, $148-150 \mathrm{~cm}$, the analcime is of the euhedral variety so well developed in Unit V. The intermediate stages consist of apparently euhedral analcime. in which a few discrete fibers can still be discerned (e.g., Sample 253-47$2,37-40 \mathrm{~cm})$.

Unit V (483-509 m)

Spectacular coarse vitric lapilli tuff and vitric ash comprise this unit. The lapilli tuff is coarsest near the top of the unit around 484 meters and between 500 and 505 meters where the individual dark-green reticulite fragments frequently exceed $15 \mathrm{~cm}$. These coarse lithologies are cemented by an abundance of analcime and calcite cements (Figure 8). At 483.5 meters the lapilli tuff shows evidence of initial (depositional) dip. A plane-parallel fabric imparted by planar lapilli and reminiscent of the eutaxitic texture found in terrestrial ash-flow tuffs is not uncommon. Frequently adjacent lapilli can be matched with their neighbors suggesting fragmentation in situ. Elsewhere in Unit V the lapilli tuff either contains much less cement or else possesses secondary smectite matrices. Macrofossil debris is absent from the lapilli tuff, but fragments have been noted in the vitric ash.

Petrography: Sample 253-52-4, $91-96 \mathrm{~cm}$ is representative (Figure 9). The moderately vesicular reticulite is texturally similar throughout the slide and is replaced by fibrous saponite and chlorite (X-ray identification by E. Fejer, Sept. 1973). Symmetrical extinction angles of the very few plagioclase microlites present in the reticulite suggests a composition of approximately An $\mathrm{n}_{65}$. Most vesicles are also filled by the saponite although a few are filled by calcite, clinoptilolite, or analcime. Some are void. Xenoliths of an older reticulite are sometimes present within the framework reticulite. 


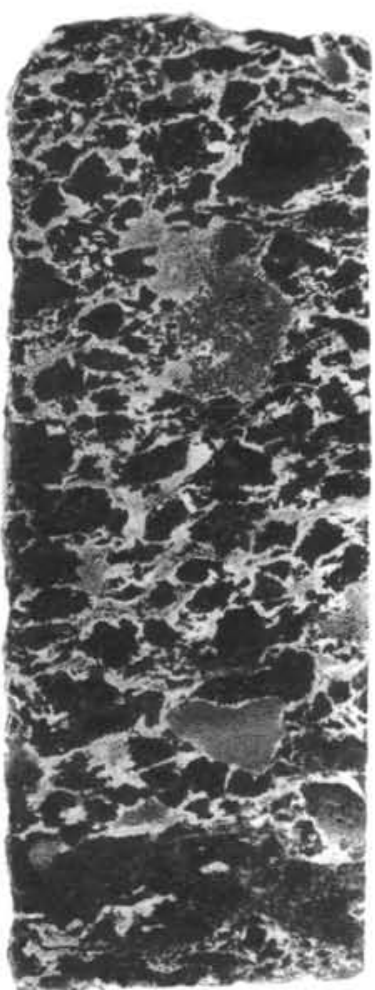

Figure 8. Unit $V$ vitric lapilli tuff (Sample 253-52-4, 43-51 $\mathrm{cm})$. Angular fragments of dark-green reticulite set in light colored analcime and calcite cements. Note the slight plane parallel fabric and the pieces of lighter colored ?xenolithic pumice present. Length of specimen 7.62 $\mathrm{cm}$.

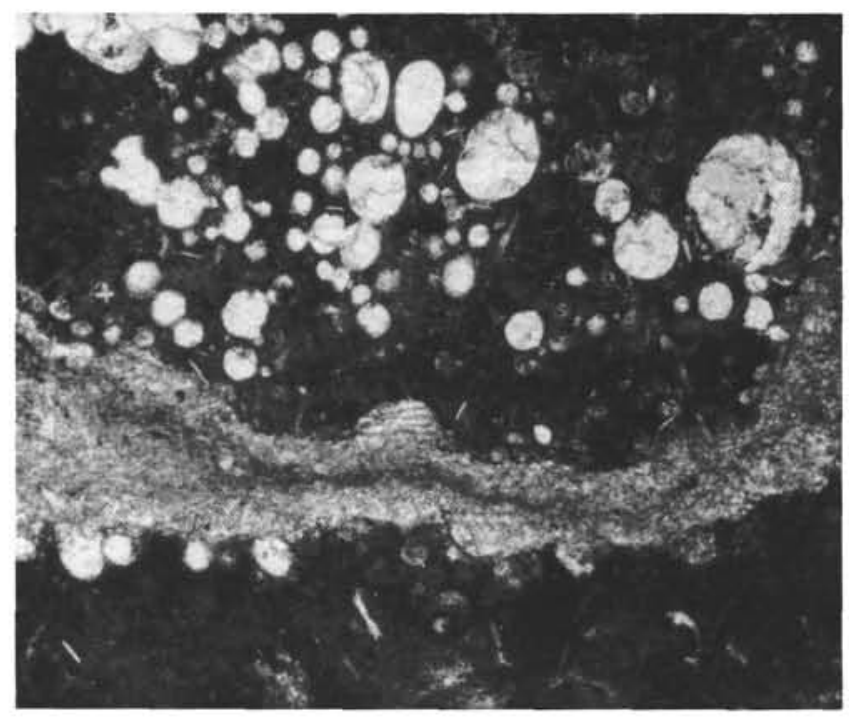

Figure 9. Unit $V$ vitric lapilli tuff (Sample 253-52-4, 91-96 $\mathrm{cm})$. Two dark-brown reticulite fragments separated by fine-grained granular analcime cement containing some scattered crystals of calcite. The two reticulite fragments exhibit contrasting degrees of vesiculation. The vesicles within the vesicular reticulite fragment are filled by relatively coarse-grained analcime. Plane light; field width $2.2 \mathrm{~mm}$.
Interstitial to the reticulite fine detrital grains are lacking. The interstices are occupied by fine-grained granular or euhedral analcime and later calcite. Fossil debris is entirely absent.

Sample 253-52-4, 116-122 cm differs in having spectacular mantles of fibrous light-green celadonite (X-ray identification by E. Fejer, Sept. 1973) developed about the reticulite fragments (Figure 10). This celadonite is peripheral to the calcite and analcime filling the interstices.

\section{Unit VI (509-558 m)}

The sediments consist of medium- to fine-grained laminated pyroclastics similar to the fine-grained laminated ash at the base of Unit IV. Vitric lapilli tuff is absent. Macrofossil debris is rare. The contact between the ash and the basalt near the bottom of the core was not preserved. It is not known whether this basalt is basement or a sill or flow within the pyroclastic sequence.

Petrography: The only thin section prepared from this unit, Sample $253-57-3,81-83 \mathrm{~cm}$, is of vitric ash, texturally very similar to that of Unit II but with all former glass now replaced by a smectite microscopically identical to that identified as saponite in Unit V.

\section{Discussion}

The widespread occurrence of calcareous-fossil debris in all units shows the sequence to be almost certainly wholly marine. There is no evidence of terrestrial sedimentation. Two periods of predominantly pyroclastic marine sedimentation represented by Units II (192.3$262.6 \mathrm{~m}$ ) and IV, V, and VI (318-554 m) alternate with two sequences of mixed pyroclasticand epiclastic detritus represented by Units I (153-192 m) and III (262$365 \mathrm{~m})$.

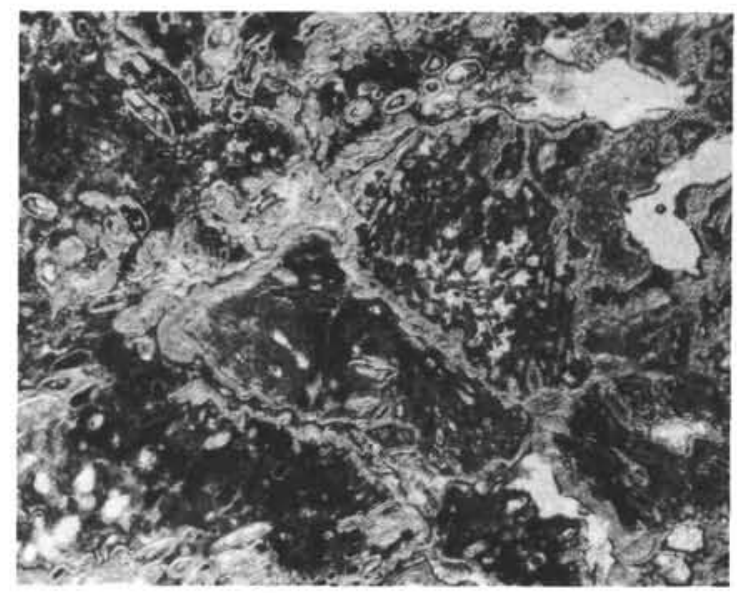

Figure 10. Unit V vitric ash (Sample 253-52-4, 116-122 cm). Dark-brown reticulite fragments devoid of microlites, surrounded by mantles of light-green fibrous celadonite. The light-colored areas interstitial to the celadonite are void or filled with analcime. Plane light; field width 2.2 $\mathrm{mm}$. 
All the tuffs are composed largely of originally holohyaline detritus and none have an appreciable pyrogenic-crystal component. When allowance is made for the highly variable and often extreme diagenetic modifications within the sequence, the pyroclastics all prove to be either vitric lapilli tuff or fine-grained vitric ash. For example, if the contrasting devitrification and diagenetic mineral assemblages and textures of the Unit II and V lapilli tuffs are ignored, these rocks are texturally very similar. Similarly, there is little textural difference between the vitric ashes of Units II and IV although their respective mineralogies now differ.

The lack of phenocrysts and even microlites within most of the tuffs examined indicates quenching of hightemperature basaltic lavas. This does suggest, at least in the case of all the lapilli tuffs composed of vesicular reticulite, the eruption or entry of lava into a shallow marine environment with quenching and simultaneous fragmentation. Such a process has been discussed by Scheidegger (1973), Heiken (1972), Walker (1972), Bonatti (1968), and Carlisle (1963). Heiken (1972) used the term phreatomagmatic eruption for this process, and several authors refer to the resulting fragmental deposits as hyaloclastics, a term originally proposed by Rittman (1962).

Because adjacent lapilli in some of the Unit $\mathrm{V}$ tuff can be matched to their neighbors, fragmentation continued after.osition while cooling continued, a process discussed at some length by Carlisle (1963, p. 61). The remarkably coarse grain size of the Unit $\mathrm{V}$ lapilli tuff and the breccia at the top of Unit I suggest that, of the sediments encountered at Site 253, these are the deposits closest to the site of their parent magmas' entry or eruption into marine environment.

The moderate-to-considerable vesicularity of the reticulite fragments in Units II, IV, V, and VI indicates fragmentation upon quenching in water of only moderate depth. An estimate of the absolute bathymetry is impossible. However, Bonatti (1968) and McBirney (1963) consider the pressures existing at depths of greater than 500 meters can prevent vesiculation in basaltic magma. Clearly then, the vesicular lapilli tuffs were quenched at depths considerably less than this figure. The quenching and fragmentation may well have been a littoral event resulting from a terrestrial lava flow crossing down a strand line into the sea. Thorarinson (1965) describes such a situation at Surtsey, and the Surtseyan hyaloclastic fragments figured by Heiken $(1972$, p. 1977) are very similar in form to the reticulite fragments of Unit V. However, overall, the Site 253 sequence shows no definite sedimentary criteria indicative of strand line or littoral sedimentation. As a result, an estimate of the bathymetry can be no more precise than to suggest a fairly shallow neritic setting.

Carlisle (1963, p. 61) has argued convincingly that quenching and fragmentation can produce "true volcanic tuffs entirely beneath water." Manyof the vitric ashes encountered at Site 253 may have been produced in this manner, but it would be impossible to distinguish them from subaerial ash-falls produced from a central vent and deposited in a marine environment. Subaqueous tuffs produced by the quenching and fragmentation mechanism envisaged by Carlisle can be widespread in their distribution. Scheidegger (1972, p. 401) maintains the ash is spread by thermal convection of the seawater above the cooling volcanic debris.

In both grades of pyroclastics at Site 253 the absence of fine-grained interstitial detritus points to the effective removal of such a size fraction by differential settling through a water column. The lapilli tuffs of Units II and V especially suggest this mechanism. Furthermore, the irregularly distributed clay-mineral matrices within the Unit IV vitric ash are considered to be largely of secondary origin and not primary vitroclastic detritus.

The presence within the Unit IV vitric ash of a detrital basaltic component that shows considerable textural and mineralogical variation and is not vitroclastic in appearance indicates come epiclastic sedimentation contemporaneous with the deposition of the pyroclastics. Such epiclastic marine sedimentation was much more prominent in the petrographically heterogeneous Unit III. It is to be admitted, however, that this apparently nonpyroclastic material could be introduced as a result of submarine phreatic eruptions through sequences of older volcanic detritus. Fiske (1963) has described such a setting from the Ohanapecosh Formation in Washington.

The thin diamictite beds present throughout the sequence reflects some sediment mobilization and redeposition. However, such a mechanism was never a major feature of the sedimentation at Site 253.

\section{Summary of Diagenesis}

The major secondary or diagenetic minerals developed in the Site 253 sequence include the two smectites, one a montmorillonite and the other saponite, and the zeolites analcime, clinoptilolite, and mordenite. The distribution of these species shows a relationship with stratigraphic depth.

Clay minerals: The fibrous moderately birefringent smectite identified as saponite in Sample 253-52-4, 5-16 $\mathrm{cm}$ is widespread in Units IV, V, and VI. The mineral replaces reticulite, fills vesicles within the same, and in Unit IV also occurs irregularly as secondary matrices. As mentioned previously, saponite replacing reticulite may carry alteration mantles of celadonite (Figure 10). The cryptocrystalline brown smectite of the montmorillonite variety and so like palagonite in appearance, is abundant in Unit II where it both replaces retigulite and shards etc. and also forms a cement in the vitroclastic sediments. Bonatti (1968, p. 467) notes that X-ray diffraction examination of hyaloclastic palagonite grains reveals the presence of montmorillonitic silicates, and so it is possible that some palagonite is also present in these Unit II lithologies. The more heterolithic sediments of Unit III appear to contain both varieties of clay minerals.

Zeolites: Analcime is present only as an interstitial cement in UnitsvIV, V, and VI and does not replace reticulite or other vitric debris. The isotropic analcime in Unit $\mathrm{V}$ is euhedral or granular and clearly a cubic mineral (Figure 11). However, as mentioned previously, younger horizons show the gradual appearance of a fibrous habit (Figure 5). 


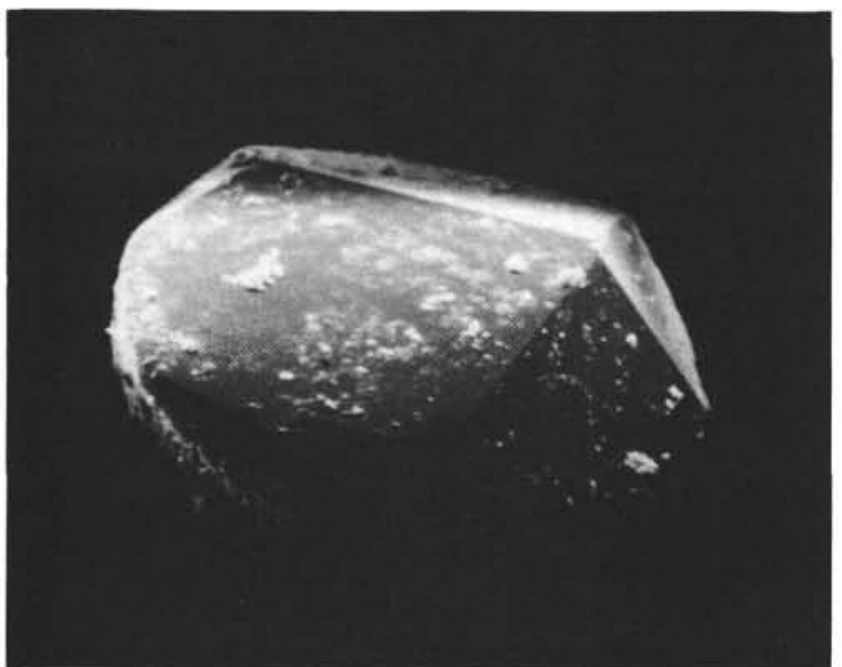

Figure 11. Analcime cement (Sample 253-54-4). SEM photograph by H. A. Buckley, British Museum. X100.

Other zeolites present include clinoptilolite and mordenite. At present their distribution in the sequence is poorly known. The former replaces some pumice fragments and shards in Units III and IV and also may fill reticulite vesicles in Unit V. Scattered patches of mordenite (X-ray identification by E. Fejer, 1973), associated with analcime, occur in Unit $\mathrm{V}$, but have not been definitely identified in thin section and the distribution of this species is still poorly known (Figure 12).

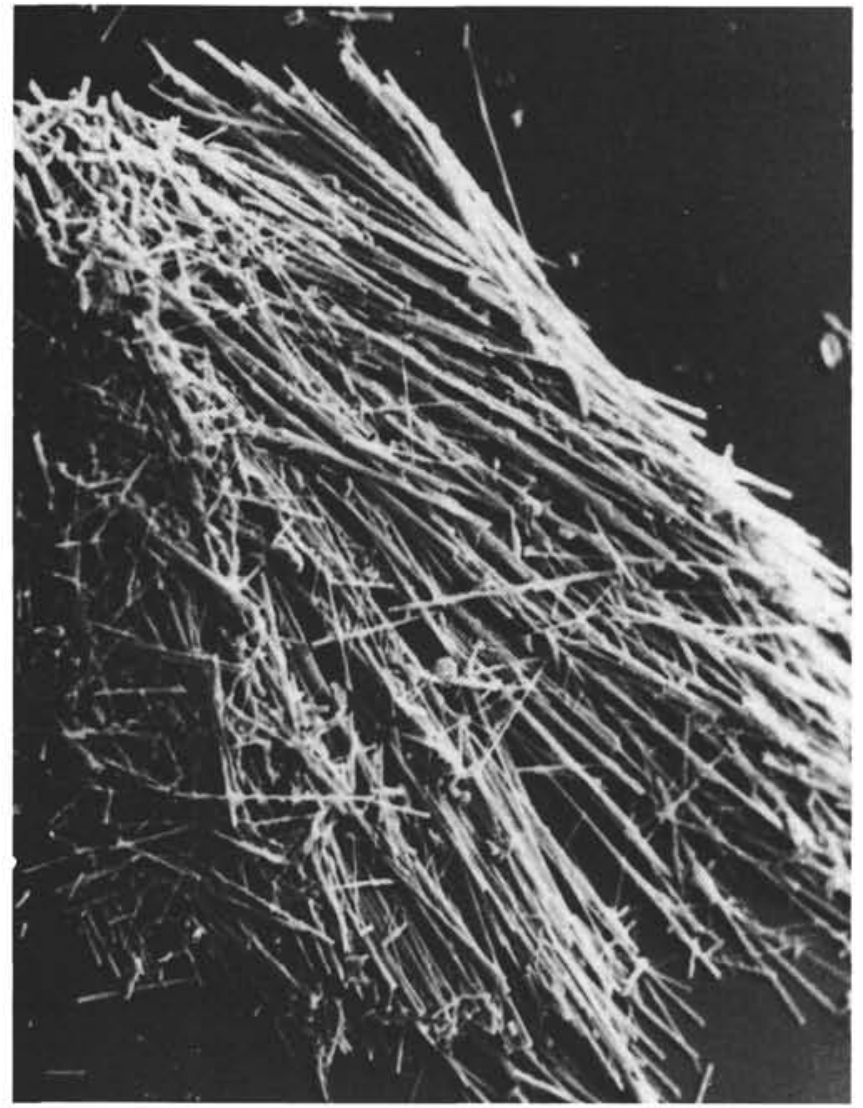

Figure 12. Mordenite (253-54, Sections 4 and 5). SEM photograph by H. A. Buckley, British Museum X92.
Thus the diagenetic minerals would appear to constitute two contrasting assemblages. A montmorillonite-clinoptilolite assemblage overlies a saponiteanalcime-clinoptilolite assemblage. The boundary between the two appears to occur within Unit III somewhere between 262.6 and 318 met. The two assemblages may reflect (a) increasing pressure and temperature conditions with depth of burial, (b) compositional differences between the older and younger tuffs, or (c) differing temperature conditions at the time of sedimentation. The semiquantitative $\mathrm{X}$-ray mineralogy data (Cook et al., this volume) suggest some of the younger horizons of the upper assemblage may be characterized by montmorillonite and the zeolite phillipsite.

The origin of these secondary mineral assemblages is beyond the scope of this short study. However, from the petrographic evidence it seems probable the two smectites and zeolites are essentially hydrothermal rather than diagenetic species, resulting from mineralogical reactions occurring at elevated temperatures during the cooling of the pyroclastic sediments.

\section{GEOCHEMISTRY}

\section{Method}

The samples were prepared as described in Fleet and Kempe (this volume, Chapter 21). Duplicate solutions were obtained by dissolving known weights of the samples, using hydrofluoric acid and perchloric acid, after drying them at $105^{\circ}-110^{\circ} \mathrm{C}$ for 3 hours and allowing them to cool in a desiccator over silica gel for $30 \mathrm{~min}$. The resulting solutions were analyzed by atomic-absorption spectrophotometry, using a PerkinElmer 303 spectrophotometer. Iron, manganese, magnesium, calcium, sodium, potassium, zinc, and copper were determined by flame; chromium, lead, cobalt, and nickel were determined by flameless spectrophotometry using a Perkin-Elmer HGA-2000 heated-graphite atomizer. The carbonate contents of the samples were calculated from the calcium and magnesium contents (determined by atomic-absorption spectrophotometry) of the filtrate obtained after mechanically shaking known weights of the samples, dried as described above, with $25 \%$ (by volume) acetic acid (it should be noted that Chester and Hughes [1967] consider that this procedure may attack other mineral phases present). The $\mathrm{H}_{2} \mathrm{O}+$ content of a number of samples were determined by an adaption of the Penfield method (Easton, 1972).

\section{Results and Discussion}

The chemical analyses of the samples are shown in Table 1, together with the analyses recalculated on a carbonate-free basis. The values for silicon, titanium, and aluminum, from Fleet and Kempe (this volume, Chapter 21) are semiquantitative and subject to certain limitations. In addition, the oxidation state of the iron is unknown, but it is probably mostly in the ferric state. Thus, a small amount of additional oxygen, the semiquantitative values for silicon, titanium, and aluminum, and the undetermined components water, sulfur, and other volatiles, result in the totals being very low. The samples were selected for analysis in an attempt to investigate the Site 253 pyroclastic sequence at regular 
TABLE 1

Chemical Analyses of Samples from the Altered Vitric Volcanic Ash Sequence, DSDP Site 253

\begin{tabular}{|c|c|c|c|c|c|c|c|c|c|c|c|c|c|c|c|c|c|c|c|c|}
\hline $\begin{array}{c}\text { Sample } \\
\text { (Interval in cm) }\end{array}$ & $\begin{array}{c}\text { Sample } \\
\text { Depth } \\
\text { Below Sea } \\
\text { Floor (m) }\end{array}$ & 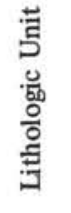 & $\begin{array}{l}\text { की } \\
\text { क } \\
\text { क }\end{array}$ & कृ & 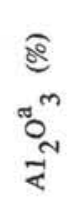 & बृ & 仓 & $\begin{array}{l}8 \\
8 \\
20\end{array}$ & $\begin{array}{l}\text { @) } \\
\text { 유 }\end{array}$ & $\begin{array}{l}\text { बृ } \\
0 \\
\text { z̃ }\end{array}$ & 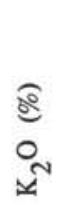 & $\begin{array}{l}\text { बृ } \\
\text { ర్ల }\end{array}$ & $\begin{array}{l}\hat{80} \\
8^{m} \\
\sum^{m}\end{array}$ & $\begin{array}{l}\text { बृ } \\
+0 \\
+0\end{array}$ & $\begin{array}{l}\hat{\Xi} \\
\text { ప્ }\end{array}$ & $\begin{array}{l}\hat{\Xi} \\
\text { है } \\
0\end{array}$ & $\begin{array}{l}\text { छે } \\
\text { ق } \\
\bar{z}\end{array}$ & $\begin{array}{l}\text { छे } \\
\text { हే }\end{array}$ & 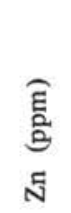 & $\begin{array}{l}\hat{\mathrm{E}} \\
\text { a } \\
\text { a }\end{array}$ \\
\hline $253-17-2,60-62$ & 153 & I & 33.0 & 1.0 & 2.7 & 14.04 & 1.10 & 3.35 & 5.19 & 3.74 & 3.04 & 2.13 & 0.53 & 7.55 & 29 & 73 & 22 & 74 & 129 & 4 \\
\hline $253-19-2,9-11$ & 172 & I & (5.1) & $(0.4)$ & $(-)$ & 8.61 & 0.20 & 2.85 & 15.56 & 2.33 & 1.79 & 36.74 & 0.95 & n. d. & 88 & 40 & 22 & 69 & 150 & 5 \\
\hline $253-20-2,90-92$ & 182 & I & $(-)$ & $(0.2)$ & $(-)$ & 4.99 & 0.15 & 2.59 & 16.20 & 2.27 & 0.67 & 50.24 & 1.37 & n. d. & 44 & 51 & 27 & 60 & 74 & 4 \\
\hline $253-21-2,58-60$ & 192 & I & 38.9 & 0.1 & 2.8 & 13.69 & 0.03 & 7.25 & 3.01 & 3.44 & 1.01 & 1.68 & 1.87 & n. d. & 10 & 15 & - & 21 & 15 & 2 \\
\hline $253-21-4,112-114$ & 195 & I I & 39.4 & 0.8 & 5.1 & 9.48 & 0.07 & 5.12 & 7.16 & 3.10 & 1.61 & 9.52 & 1.49 & n. d. & 33 & 49 & - & 81 & 113 & 2 \\
\hline $253-23-2,86-88$ & 211 & I I & 30.8 & 0.2 & 5.9 & 6.73 & 0.14 & 4.33 & 10.39 & 2.72 & 1.74 & 18.90 & 1.59 & n. d. & 108 & 50 & 81 & 90 & 54 & 2 \\
\hline $253-26-2, \quad 23-25$ & 239 & I I & 54.6 & 0.6 & 8.1 & 8.22 & 0.05 & 7.00 & 5.15 & 3.36 & 1.01 & 1.86 & 0.94 & 8.69 & 89 & 64 & 59 & 180 & 85 & 3 \\
\hline $253-28-2,18-19$ & 252 & I I & (11.6) & $(0.2)$ & $(0.9)$ & 5.99 & 0.44 & 5.73 & 9.71 & 2.55 & 0.82 & 17.75 & 1.04 & n. d. & 75 & 42 & 17 & 139 & 56 & 2 \\
\hline $253-30-1,120-122$ & 271 & I I I & $(10.5)$ & $(0.2)$ & $(0.2)$ & 8.33 & 0.13 & 3.30 & 15.86 & 1.36 & 1.82 & 39.18 & 0.55 & n. $d$. & 73 & 39 & 11 & 29 & 97 & 4 \\
\hline $253-36-1,93-95$ & 327 & IV & 52.6 & 0.2 & 5.7 & 5.48 & 0.01 & 6.05 & 2.65 & 3.43 & 0.84 & 0.99 & 0.80 & n. d. & 20 & 16 & - & 60 & 105 & 3 \\
\hline $253-41-1,100-102$ & 375 & IV & 41.3 & 2.0 & 6.1 & 13.36 & 0.12 & 4.79 & 2.37 & 2.22 & 1.76 & 6.61 & 0.70 & 6.11 & 26 & 65 & 6 & 85 & 217 & 4 \\
\hline $253-44-2,80-82$ & 405 & IV & $(9.2)$ & $(0.2)$ & $(0.4)$ & 9.89 & 0.09 & 7.37 & 2.94 & 1.75 & 1.99 & 16.22 & 0.89 & n. d. & 90 & 67 & 28 & 89 & 89 & 8 \\
\hline $253-45-2,110-113$ & 415 & IV & 35.7 & 0.8 & 3.2 & 12.19 & 0.06 & 6.76 & 1.36 & 3.91 & 1.39 & 9.18 & 1.30 & n. d. & 61 & 56 & 23 & 134 & 101 & 2 \\
\hline $253-46-5,110-112$ & 429 & IV & $(22.0)$ & $(0.5)$ & (2.7) & 10.23 & 0.11 & 6.66 & 5.02 & 3.46 & 2.52 & 15.54 & 0.73 & n. d. & 85 & 65 & 14 & 129 & 116 & 3 \\
\hline $253-48-2,91-94$ & 443 & IV & 34.7 & 0.3 & 4.2 & 10.33 & 0.08 & 7.51 & 2.42 & 4.37 & 1.16 & 5.84 & 1.15 & n. d. & 101 & 66 & 114 & 162 & 74 & 3 \\
\hline $253-52-2,50-52$ & 481 & IV & 33.2 & 0.6 & 7.0 & 8.60 & 0.08 & 6.42 & 2.07 & 3.17 & 1.79 & 13.74 & 0.46 & 6.50 & 110 & 55 & 29 & 100 & 96 & 3 \\
\hline $253-53-2,137-140$ & 491 & V & 34.2 & 0.2 & 4.7 & 7.98 & 0.13 & 7.21 & 1.72 & 5.33 & 0.23 & 6.61 & 0.67 & n. d. & 149 & 56 & 75 & 145 & 81 & 4 \\
\hline $253-54-5,115-117$ & 505 & V & $(36.4)$ & $(0.2)$ & $(-)$ & 9.36 & 0.10 & 8.74 & 1.35 & 3.34 & 0.36 & 2.94 & 1.12 & n. d. & 152 & 54 & 83 & 127 & 65 & 2 \\
\hline $253-56-2,50-52$ & 519 & VI & 38.5 & 0.2 & 6.4 & 5.52 & 0.08 & 2.89 & 1.20 & 1.37 & 0.72 & 9.33 & 0.34 & n. d. & 37 & 41 & 2 & 64 & 55 & 2 \\
\hline $253-57-2,85-88$ & 547 & VI & 26.5 & 1.3 & 5.1 & 10.29 & 0.21 & 7.09 & 3.27 & 1.72 & 1.55 & 15.98 & 0.75 & 5.01 & 64 & 49 & 20 & 114 & 111 & 2 \\
\hline
\end{tabular}

Note: n.d. = Not determined; - Not detected.

${ }_{b}^{\mathrm{a}}$ Elements determined by direct-reading spectrography, values in parenthesis are unreliable (see Fleet and Kempe, this volume, Chapter 21.)

$\mathbf{b}_{*=\text { Total iron assuming it is all in the ferrous state. }}$ 


\begin{tabular}{|c|c|c|c|c|c|c|c|c|c|c|c|c|c|c|c|}
\hline \multicolumn{16}{|c|}{ Results Recalculated on a Carbonate-Free Basis } \\
\hline 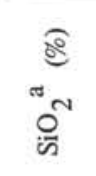 & 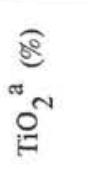 & 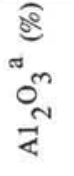 & 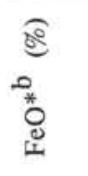 & $\begin{array}{l}80 \\
8 \\
\frac{0}{2}\end{array}$ & 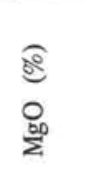 & $\begin{array}{l}\text { बీ } \\
\text { ᄋ్ }\end{array}$ & 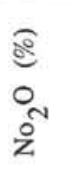 & $\begin{array}{l}\widehat{e} \\
0 \\
0 \\
0\end{array}$ & $\begin{array}{l}\sqrt{8} \\
+0 \\
+ \\
{ }^{2}\end{array}$ & $\begin{array}{l}\bar{E} \\
\text { ô } \\
\text { y }\end{array}$ & $\begin{array}{l}\bar{E} \\
\overline{0} \\
8\end{array}$ & $\begin{array}{l}\text { ह } \\
\text { ఏ్ర } \\
\dot{z}\end{array}$ & $\begin{array}{l}\widehat{E} \\
\text { 总 } \\
\text { 己 }\end{array}$ & 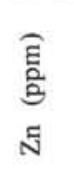 & $\begin{array}{l}\widehat{\bar{E}} \\
\text { 영 } \\
\text { 을 }\end{array}$ \\
\hline 34.1 & 1.1 & 2.7 & 14.54 & 1.14 & 3.47 & 5.37 & 3.87 & 3.15 & 7.82 & 30 & 76 & 23 & 77 & 134 & 4 \\
\hline (11.3) & $(0.9)$ & $(-)$ & 19.03 & 0.44 & 6.30 & 34.40 & 5.15 & 3.96 & n. d. & 160 & 73 & 40 & 126 & 273 & 9 \\
\hline$(-)$ & $(0.5)$ & $(-)$ & 12.33 & 0.37 & 6.40 & 40.04 & 5.61 & 1.66 & n. d. & 109 & 126 & 67 & 148 & 183 & 10 \\
\hline 40.7 & 0.1 & 3.0 & 14.31 & 0.03 & 7.58 & 3.15 & 3.60 & 1.06 & n. d. & 10 & 16 & - & 22 & 16 & 2 \\
\hline 44.8 & 0.9 & 5.8 & 10.79 & 0.08 & 5.83 & 8.15 & 3.53 & 1.83 & n. d. & 38 & 56 & - & 92 & 129 & 2 \\
\hline 39.8 & 0.3 & 7.6 & 8.69 & 0.18 & 5.59 & 13.41 & 3.51 & 2.25 & n. d. & 139 & 65 & 105 & 116 & 70 & 3 \\
\hline 56.1 & 0.6 & 8.4 & 8.46 & 0.05 & 7.20 & 5.30 & 3.46 & 1.04 & 8.94 & 92 & 66 & 61 & 185 & 87 & 3 \\
\hline (16.3) & $(0.2)$ & $(-)$ & 8.47 & 0.62 & 8.10 & 13.73 & 3.61 & 1.16 & n. d. & 106 & 59 & 24 & 197 & 79 & 3 \\
\hline (19.0) & $(0.4)$ & $(-)$ & 15.06 & 0.24 & 5.97 & 28.68 & 2.46 & 3.29 & n. d. & 132 & 71 & 20 & 52 & 175 & 7 \\
\hline 53.9 & 0.2 & 5.8 & 5.61 & 0.01 & 6.19 & 2.71 & 3.51 & 0.86 & n. d. & 20 & 16 & - & 61 & 107 & 3 \\
\hline 45.1 & 2.1 & 6.6 & 14.58 & 0.13 & 5.23 & 2.59 & 2.42 & 1.92 & 6.67 & 29 & 71 & 7 & 93 & 238 & 4 \\
\hline (13.1) & $(0.3)$ & $(0.5)$ & 14.08 & 0.13 & 10.50 & 4.19 & 2.49 & 2.83 & n. d. & 128 & 95 & 40 & 127 & 127 & 11 \\
\hline 40.9 & 0.9 & 3.7 & 13.97 & 0.07 & 7.74 & 1.56 & 4.48 & 1.59 & n. d. & 70 & 64 & 26 & 154 & 116 & 2 \\
\hline (28.0) & $(0.7)$ & (3.4) & 13.02 & 0.14 & 8.48 & 6.39 & 4.40 & 3.21 & n. d. & 108 & 83 & 18 & 164 & 148 & 4 \\
\hline 38.1 & 0.3 & 4.6 & 11.34 & 0.09 & 2.66 & 8.24 & 4.80 & 1.27 & n. d. & 111 & 72 & 125 & 178 & 81 & 3 \\
\hline 40.0 & 0.7 & 8.4 & 10.36 & 0.10 & 7.73 & 2.49 & 3.82 & 2.16 & 7.83 & 133 & 66 & 35 & 120 & 116 & 4 \\
\hline 37.9 & 0.2 & 5.2 & 8.84 & 0.14 & 7.99 & 1.90 & 5.90 & 0.25 & n. d. & 165 & 62 & 83 & 161 & 90 & 4 \\
\hline (38.6) & $(0.2)$ & $(-)$ & 9.94 & 0.11 & 9.28 & 1.43 & 3.55 & 0.38 & n. d. & 161 & 57 & 88 & 135 & 69 & 2 \\
\hline 44.4 & 0.3 & 7.4 & 6.37 & 0.09 & 3.33 & 1.38 & 1.58 & 0.83 & n. d. & 43 & 47 & 2 & 74 & 63 & 2 \\
\hline 33.7 & 1.7 & 6.5 & 13.06 & 0.27 & 9.00 & 4.15 & 2.18 & 1.97 & 6.36 & 81 & 62 & 25 & 145 & 141 & 3 \\
\hline
\end{tabular}

Note: n.d. $=$ Not determined; - Not detected.

${ }^{a}$ Elements determined by direct-reading spectrography, values in parenthesis are unreliable (see Fleet and Kempe, Chapter 21 , this volume).

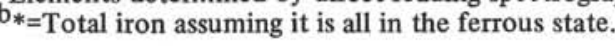


intervals, though, unfortunately, Unit III and the top of Unit IV are poorly represented. These samples were analyzed as part of a geochemical study being carried out on samples from Leg 26, the preliminary results of which are reported elsewhere in this volume (Fleet and Kempe, Chapter 21).

The variable and often extreme degree of alteration within the sequence, together with the uncertain relationships inherent in the sampling technique (Walker, 1973), make it very difficult to draw petrogenetic conclusions regarding the source or sources of the sequence. However, the concentrations of the rare-earth elements in samples from this sequence and the volcanilastic sediments from Site 254, seen also in the similar trending rare earth data fro a sample of the basal volcanogenic sands from the bottom of Hole 258 (Fleet and Kempe, Chapter 21), are consistent with the suggestion of Thompson et al. (1974) and Frey et al. (this volume, Chapter 23) that the Ninetyeast Ridge may be the surface expression of a former mantle plume.

The transformation of volcanic glass can be idealized as a hydration reaction but is, in fact, more complex (Hay, 1966). Such alteration of tuffs can lead to the gain of an element, relative to its concentration in the unaltered tuff, at one horizon and its loss at another, at a single locality (Hay and Iijima, 1968). The geochemistry of the Site 253 sequence emphasizes its altered nature. As was discussed in the Petrography Section of this paper, the alteration products are divisible basically into a montmorillonite-clinoptilolite assemblage overlying a saponite-analcime-clinoptilolite assemblage.

The elemental concentrations on a carbonate-free basis shown in Table 1 represent variations due to hydrothermal alteration, as a result of which two smectites and analcime are considered to have formed, and to postdepositional migratory and other diagenetic effects. The semiquantitative analyses of silica, titania, and alumina show that the concentrations of these elements may vary, presumably at least in part due to differential alteration, but not in a way readily relatable to the units making up the sequence. The relatively high concentrations of titania found in some samples may be due to the diagenetic formation of anatase, which is found (Cook, Zemmels, and Matti, this volume, Chapter 24) in Cores 38 to 57 . The values determined for calcium oxide, potassa, and to a lesser extent soda, on a carbonate-free basis, also vary unsystematically. Similarly, the magnesia contents of the samples vary, but are generally higher for samples from Units IV, V, and VI (Figure 13), which contain a relatively magnesium-rich smectite, saponite, possibly representing the alteration of pyroclastic material formed from a magnesium-rich magma. The difference in chemistry of the parent magma of the upper and lower mineral assemblages which is implied by this is also suggested by the magnesium-rich, highly olivine-normative, nature of the "basement" basalt (Sample 253-58-1, 2-7 cm) compared to the quartz-normative flow basalt (Sample 25324-1, 84-85 cm), both of which are discussed elsewhere (Kempe, this volume, Chapter 14; Frey and Sung, this volume, Chapter 23). Furthermore, a plot of the norms calculated for some of the samples, while having no

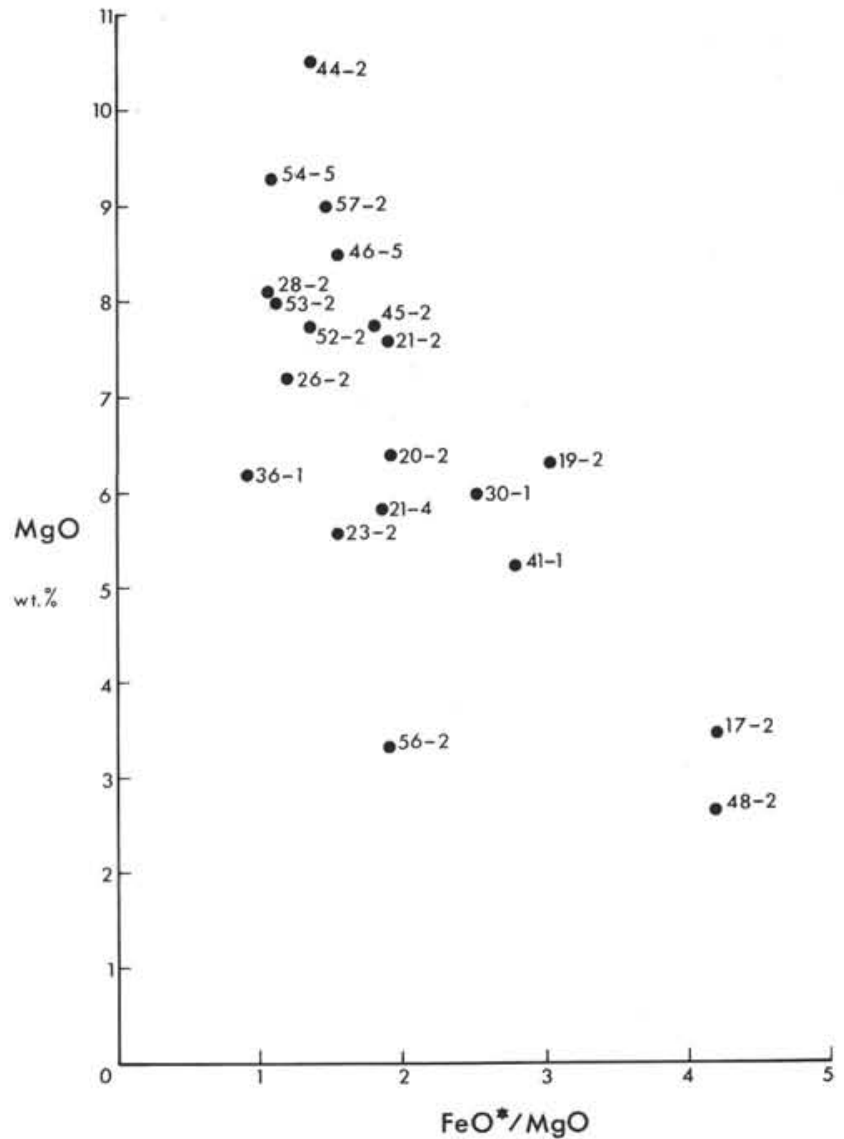

Figure 13. The $\mathrm{MgO}$ contents of analyzed samples plotted against the $\mathrm{FeO} / \mathrm{MgO}$ ratios of the samples.

readily discernible pattern, probably because of alteration and the fact that some of the results used were semiquantitative indicated that a number of the samples from the lower three units fall near the olivine corner, in both olivine basalt and olivine tholeiite fields, while samples from higher in the sequence fall in or near the quartz tholeiite field. Units I and III have higher iron contents than Unit II, and this probably reflects the differing genesis of the latter, predominantly pyroclastic, unit compared to the mixed pyroclastic and epiclastic origins of Units I and III. The variation of iron in the lower three units (Table 1), excepting the uppermost and lowest samples, shows a decrease with depth, which suggests postdepositional migration of the iron, probably with leaching from the underlying basalt affecting the lowest sample. This effect is superimposed on the other major element alteration which is due chiefly to syngenetic hydrothermal alteration. Mangenese also seems to be affected by postdepositional migration throughout the sequence, decreasing in concentration with depth from the top of the sequence and then again from about 250 meters beneath the sea floor, beyond which point the suggested migration does not seem to have continued upwards. Relatively high manganese concentrations, probably due to leaching, are found in the samples above the flow and basement basalts. The concentrations of the trace 
elements vary with depth except for the cobalt values. The zinc distribution, which during weathering is controlled by the solubility of its compounds (Wedepohl, 1970), appears to correlate with iron (Figure 13), the oxide phases of which may adsorb it.

Thus, the available mineralogical studies on the volcaniclastics from Leg 26 , the whole sediment analyses of this sequence, and the preliminary geochemical work on the volcaniclastics from Sites 254 and 258 (Fleet and Kempe, this volume, Chapter 21) show that variable alteration of these sediments has occurred. Analyses of samples representative of these lithologies are being completed using atomic-absorption spectrophotometry, neutron-activation analysis, and other methods; the nature of the alterations which have occurred will be further investigated employing techniques such as microprobe analysis.

\section{ACKNOWLEDGMENTS}

We are grateful to Miss Eva Fejer of the Department of Mineralogy, British Museum (Natural History) for six X-ray identifications of clay minerals and zeolites; to H. A. Buckley, of the same department, for an SEM photograph of analcime; and to K. W. Richardson and R. Shaw, Department of Geology, Chelsea College, University of London, for their help and advice with the atomic-absorption spectrophotometry. T. L. Vallier kindly reviewed the manuscript and made many helpful suggestions for improvements. A. J. F. acknowledges the receipt of an NERC Joint Research Studentship.

\section{REFERENCES}

Bonatti, E., 1968. Mechanisms of deep sea volcanism in the South Pacific. In Abelson, P. H. (Ed), Researches in geochemistry: New York (Wiley).

Carlisle, D., 1963. Pillow breccias and their aquagene tuffs, Quadra Island British Columbia: J. Geol., v. 71, p. 48.

Chester, R. and Hughes, M. J., 1967. A chemical technique for the separation of ferro-manganese minerals, carbonate minerals and adsorbed trace elements from pelagic sediments: Chem. Geol., v. 2, p. 249-262.

Easton, A. J., 1972. Chemical analysis of silicate rocks: New York (Elsevier).

Fiske, R. S., 1963. Subaqueous pyroclastic flows in the Ohanapecosh Formation, Washington: Geol. Soc. Am. Bull., v. 74 , p. $391-406$

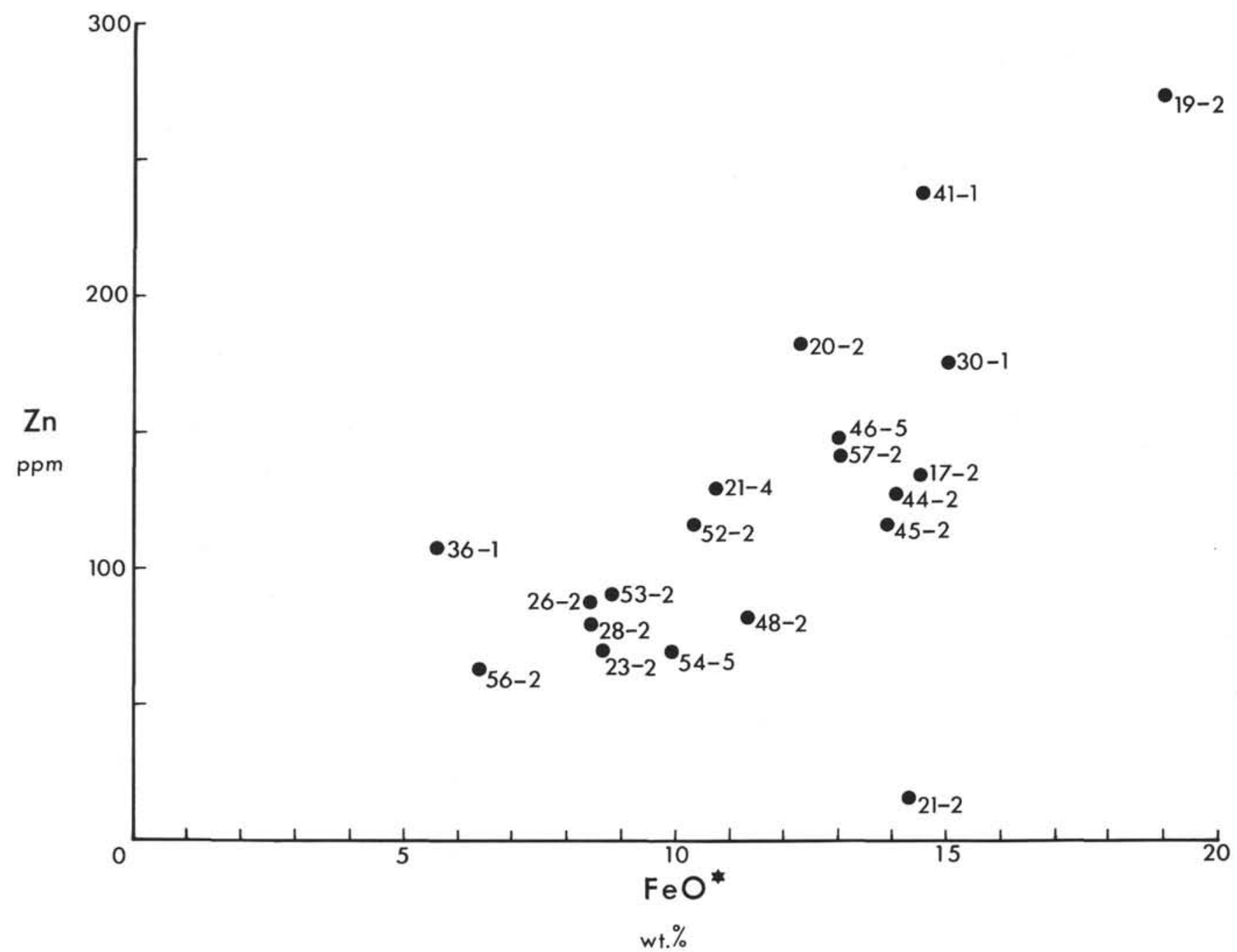

Figure 14. The $\mathrm{Zn}$ contents of analyzed samples plotted against the $\mathrm{FeO}$ contents of the samples. 
Flint, R. F., Sanders, J. E., and Rodgers, J., 1960. Diamictite, a substitute for the term symmictite: Geol. Soc. Am. Bull., v. 71, p. 1809

Hay, R. L., 1966. Zeolites and zeolitic reactions in sedimentary rocks: Geol. Soc. Am. Spec. Paper, 85.

Hay, R. L. and Iijima, A., 1968. Nature and origin of palagonite tuffs of the Honolulu Group on Oahu, Hawaii. In Coats, R. R., Hay, R. L., and Anderson, C. A. (Eds), Studies in volcanology: Geol. Soc. Am. Mem. 116, p. 331376.

Heiken, G., 1972. Morphology and petrology of volcanic ashes: Geol. Soc. Am. Bull., v. 83, p. 1961-1988.

McBirney, A. R., 1963. Factors governing the nature of submarine volcanism: Volcanol. Bull., v. 26, p. 455.

Rittman, A., 1962. Volcanoes and their activity: New York, (John Wiley and Sons).

Scheidegger, K. F., 1973. Volcanic ash layers in deep sea sediments and their petrological significance: Earth Planet. Sci. Lett., v. 17, p. 397-407.
Thompson, G., Byran, W. B., Frey, F. A., and Sung, C. M., 1974. Petrology and geochemistry of basalts and related rocks from Sites 214, 215, 216, DSDP Leg 22, Indian Ocean. In von der Borch, C. C., and Slater, J. G., et al., Initial Reports of the Deep Sea Drilling Project, Volume 22: Washington (U.S. Government Printing Office), p. 459.

Thorarinson, S., 1965. The Surtsey eruption, course of events and the development of the new island: Surtsey Research Program Rept. I., Reykjavik, Iceland.

Walker, G. P. L., 1972. Petrology of the volcanic hyaloclastic sandstone. In Laughton, A. S., Berggren, W. A., et al., Initial Reports of the Deep Sea Drilling Project, Volume 12: Washington (U. S. Government Printing Office), p. 365-369.

1973. The imbalance between volcanology and geochemistry (abs): J. Geol. Soc. London Proc., v. 129, p. 648.

Wedepohl, K. H., 1970. Zinc: In Wedepohl, K. H. (Ed.) Handbook of geochemistry, v. II/2, New York (SpringerVerlag). 